\title{
Testicular Brenner Tumor
}

National Cancer Institute

\section{Source}

National Cancer Institute. Testicular Brenner Tumor. NCI Thesaurus. Code C39953.

An uncommon usually benign neoplasm that arises from the testis. It is characterized by

the presence of cysts lined by transitional cells and solid nests of transitional cells in a spindle cell stroma. 